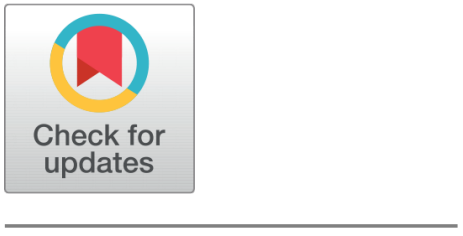

OPEN ACCESS

Received: 13.01.2021

Accepted: 28.02.2021

Published: 23.03 .2021

Citation: Ombiro SO, Olatunji AS, Mathu EM, Ajayi TR (2021)

Application of remote sensing in mapping hydrothermally altered zones in a highly vegetative area - A case study of Lolgorien, Narok County, Kenya. Indian Journal of Science and Technology 14(9): 810-825. https://doi.org/ 10.17485/IJST/v14i9.68

* Corresponding author. sombiro@jkuat.ac.ke

Funding: African Union through the Pan-African University, Life and Earth Sciences Institute (including Health and Agriculture), University of Ibadan, Nigeria (PAULESI)

Competing Interests: None

Copyright: (c) 2021 Ombiro et al. This is an open access article distributed under the terms of the Creative Commons Attribution License, which permits unrestricted use, distribution, and reproduction in any medium, provided the original author and source are credited.

Published By Indian Society for Education and Environment (iSee)

ISSN

Print: 0974-6846

Electronic: 0974-5645

\section{Application of remote sensing in mapping hydrothermally altered zones in a highly vegetative area - A case study of Lolgorien, Narok County, Kenya}

\author{
Sammy O Ombiro ${ }^{1 *}$, Akinade S Olatunji ${ }^{2}$, Eliud M Mathu ${ }^{3}$, Taiwo R Ajayi ${ }^{2}$ \\ 1 Pan African University, Life and Earth Sciences Institute, University of Ibadan, Nigeria \\ 2 Department of Geology, University of Ibadan, Nigeria \\ 3 Department of Geology and Meteorology, South Eastern Kenya University, Kenya
}

\section{Abstract}

Objective: To map areas of possible hydrothermal alteration using remote sensing technology; To map geological structures controlling mineralisation using remote sensing; To carryout field mapping to ground truth the features identified by remote sensed data. Methods: Landsat 8 Operational Land Imager (OLI) and Shuttle Radar Topography Mission (SRTM) remote sensed images were downloaded from USGS website. Landsat images were processed using band ratios, band composites, principal component analysis techniques in ArcGIS to map areas of possible hydrothermal alteration. SRTM image was analysed using hillshade analysis technique in ArcGIS to map geological structural features controlling mineralisation. Findings: The study found that in several areas especially Southern, South Eastern, Central and North Western part of Lolgorien, there is a possibility of hydrothermal alteration as spectral signatures associated with iron oxide and clay minerals were identified. It was also found that areas with possibility of hydrothermal alteration are also associated with relatively large number of lineaments. It was also found that Southern and South-Eastern part of Lolgorien are also associated with numerous artisanal mines proving the fact that indeed gold mineralisation may be found in these places. However, due to thick vegetation cover, mapping of different types of lithological units found in Lolgorien was not possible. Novelty/Application: The application of remote sensed technology helped in identification of new areas of possible mineralisation such as Central and North-Western parts of Lolgorien which despite having similar geological properties (in terms of lineament density and hydrothermal alteration) have never been exploited for gold or other minerals.

Keywords: Hydrothermal alteration; Landsat 8 (OLI); SRTM; Iron oxide; clay minerals; remote sensing 


\section{Introduction}

Even though it is not possible to directly see or delineate gold mineralisation using remote sensed satellite images, the mineralisation can be indirectly mapped using remote sensing as it is associated with several minerals which exhibit unique spectral properties (spectral reflectance) ${ }^{(1)}$. These minerals are usually found in hydrothermally altered zones. According to ${ }^{(2,3)}$, examples of these minerals are Kalinite, Illite $(1 \mathrm{M}$ and $2 \mathrm{M})$ and Dioctahedral smectite. The minerals have unique spectral signatures in the shortwave infrared section of the electromagnetic spectrum making them detectable by remote sensing ${ }^{(3)}$. As result, the spectral signatures associated with them can be used to map areas with possible gold mineralisation.

Generally, clay minerals (Kalinite, Illite and Dioctahedral smectite) are associated with gold mineralisation and, as a result, their identification may help in the search for gold mineralisation. Gold mineralisation may also be associated with iron oxides such as banded iron formations as is the case of Lolgorien and other places around the world. This means that delineation of banded iron formation and other iron oxides may lead to the finding of a gold mineralisation. Clay minerals and iron oxides are products of hydrothermal alteration and it is the hydrothermal fluids (mineralising fluid) that carry with them gold and other minerals. Therefore, areas that have undergone hydrothermal alteration may be mapped by identification of zones with clay minerals and iron oxides. This can be done using remote sensing.

The use of remote sensing in delineation of hydrothermal alteration (identification of clay minerals and iron oxides) as a way of mapping zones with potential of gold mineralization have been applied in several previous studies. A study by ${ }^{(4)}$ utilised remote sensing approach to delineate hydrothermal zones and structures in Guelma basin, Northeastern Algeria. $\operatorname{In}^{(3)}$, integration of remote sensing technique with other techniques were used to map clay minerals (hydrothermal alteration) that maybe associated with gold mineralisatiomn in Roodepoort and Westonaria in Gauteng Province, and Witbank and Kriel in Mpumalanga Province, all of which are located in South Africa. They concluded that when interated with other techniques, remote sensing through mapping of clay minerals can be used delineate areas with possible gold ( $\mathrm{Au}$ ), Silver (Ag) and Tin (Sn) and Tungsten (W) mineralisation. $\mathrm{In}^{(5)}$, remote sensing was used to successfully delineate areas with iron bearing minerals (especially ferric and ferrous oxides) in Wadi Allaqi area, South Eastern Desert of Egypt. In ${ }^{(6)}$, remote sensing techniques were applied to discriminate areas with potential of iron-based minerals in Sar Cheshmeh copper mining district, south-eastern Islamic Republic of Iran using Landsat 8 (OLI) images. In this study, the band ratios with bright pixels helped delineated areas with potential of iron bearing minerals. ${ }^{(7)}$ also applied remote sensing techniques such as band combinations, band ratios and composite to successfully map hydrothermal minerals associated with gold mineralisation in Southern Tianshan area, China. The researchers used ASTER data in this process, and they concluded that VNIR (visible and near-infrared) and SWIR (Shortwave infrared) bands were the most effective for mapping hydrothermal minerals from the ASTER (Advanced Spaceborne Thermal Emission and Reflection Radiometer) images. In ${ }^{(8-10)}$, remote sensing technique was used to accurately map gold mineralisation in Gauteng and Mpumalanga Provinces, South Africa by mapping clay minerals which are often associated with gold mineralisation.

$\mathrm{In}^{(11,12)}$, ASTER remote sensing imagery was used to map and discriminate phyllosilicate mineral groups and listvenite occurrences, in Antarctic environment of Northern Victoria Land. Using VNIR, SWIR and thermal-infrared (TIR) bands of ASTER, the authors were able to delineate $\mathrm{Al}, \mathrm{Fe} 3+-$ rich, $\mathrm{Fe} 2+$ and $\mathrm{Mg}$ phyllosilicates rich rocks. In ${ }^{(13)}$ by using VNIR and SWIR bands of Landsat-8, Sentinel-2, ASTER and WorldView-3 (WV-3) remote sensed images, the authors were able to discriminate areas associated with $\mathrm{Zn}-\mathrm{Pb}$ mineralisation in the central part of the Kashmar-Kerman Tectonic Zone, Central Iranian Terrane. $\mathrm{In}^{(14)}$, the authors used band ratio Principle component analysis to process Landsat Enhanced Thematic Mapper + (Landsat-7 ETM+), Landsat-8 and ASTER images so as to map hydrothermal alteration zones that may be associated with epithermal gold mineralization in the Ahar-Arasbaran region, North West Iran. In ${ }^{(15)}$, Landsat-8, ASTER and WorldView3 multispectral remote sensing data were used to map hydrothermal alteration associated with copper-gold mineralisation in Northeastern Inglefield Mobile Belt (IMB), Northwest Greenland. In ${ }^{(16)}$, authors used Sentinel-1, ASTER, Phased Array type L-band Synthetic Aperture Radar (PALSAR) and Sentinel-2 to map regional structural units that control gold mineralisation in Barramiya-Mueilha Sector, Egypt. In ${ }^{(17)}$, multispectral and Synthetic Aperture Radar (SAR), Landsat 8 (OLI), ASTER, PALSAR and Sentinel-1B data were processed using band rationing, independent component analysis, principal component analysis, automated and semi-automated lineament extraction, and directional filtering to map zones of possible gold mineralisation and structural features controlling the mineralisation in South Eastern Desert, Egypt.

Lolgorien is one of the most active gold mining areas in Kenya hosting Kilimapesa Gold Mine and a number of artisanal mines. Despite its contribution to Kenya's gold mining industry, it is one of the most understudied geological settings in Kenya. Additionally, despite the current improvement in mineral exploration technologies such as application of remote sensing technique, little effort has been made to update the mineralised zones, structural features and geological units using the technique. This means that gold mineralisation and the associated minerals (such as iron oxides and clay minerals) in the area have never been mapped using remote sensing technique. Furthermore, no recent geological study has been carried out 
in the area except for the ones carried out by interested mining companies. The most recent known (to the best knowledge of the authors) geological study carried out in the area other than the ones being carried out by mining companies was carried out in 1991 by $^{(18)}$. But ${ }^{(18)}$ 's study never incorporated remote sensing in identification mineralised areas. A study by ${ }^{(19)}$ in the 1940s which was done on behalf of the Geological Survey of Kenya, mapped geological units found in the study area. It is, however, important to note that by this time (1940s), remote sensed data were not readily available and it is highly unlikely that Shackleton (1946) used remote sensed images to map Lolgorien's gold mineralisation and geological units. This study attempts to bridge this gap by employing a relatively modern technology (remote sensing technology) to map hydrothermal minerals such as clay minerals and iron oxides which may be associated with gold mineralisation in Lolgorien.

\section{Methodology}

\subsection{Study location}

Lolgorien Sub-county is located in Western part of Kenya within the Great Rift Valley, in Narok County. It is approximately $223 \mathrm{~km}$ from Nairobi (the Kenyan capital city), and its approximate geographical coordinate is between $1^{\circ} 09^{\prime} 0^{\prime \prime} \mathrm{S}$ to $1^{\circ} 15^{\prime} 0$ $\mathrm{S}$ and $34^{\circ} 44^{\prime} 0^{\prime \prime} \mathrm{E}$ to $34^{\circ} 55^{\prime} 0^{\prime \prime}$ E. Lolgorien area receives moderate rainfall and as a result, the area is covered by moderate to thick forest (vegetation) is some areas and grass lands in other areas. The location of the study area is shown in Figure 1.

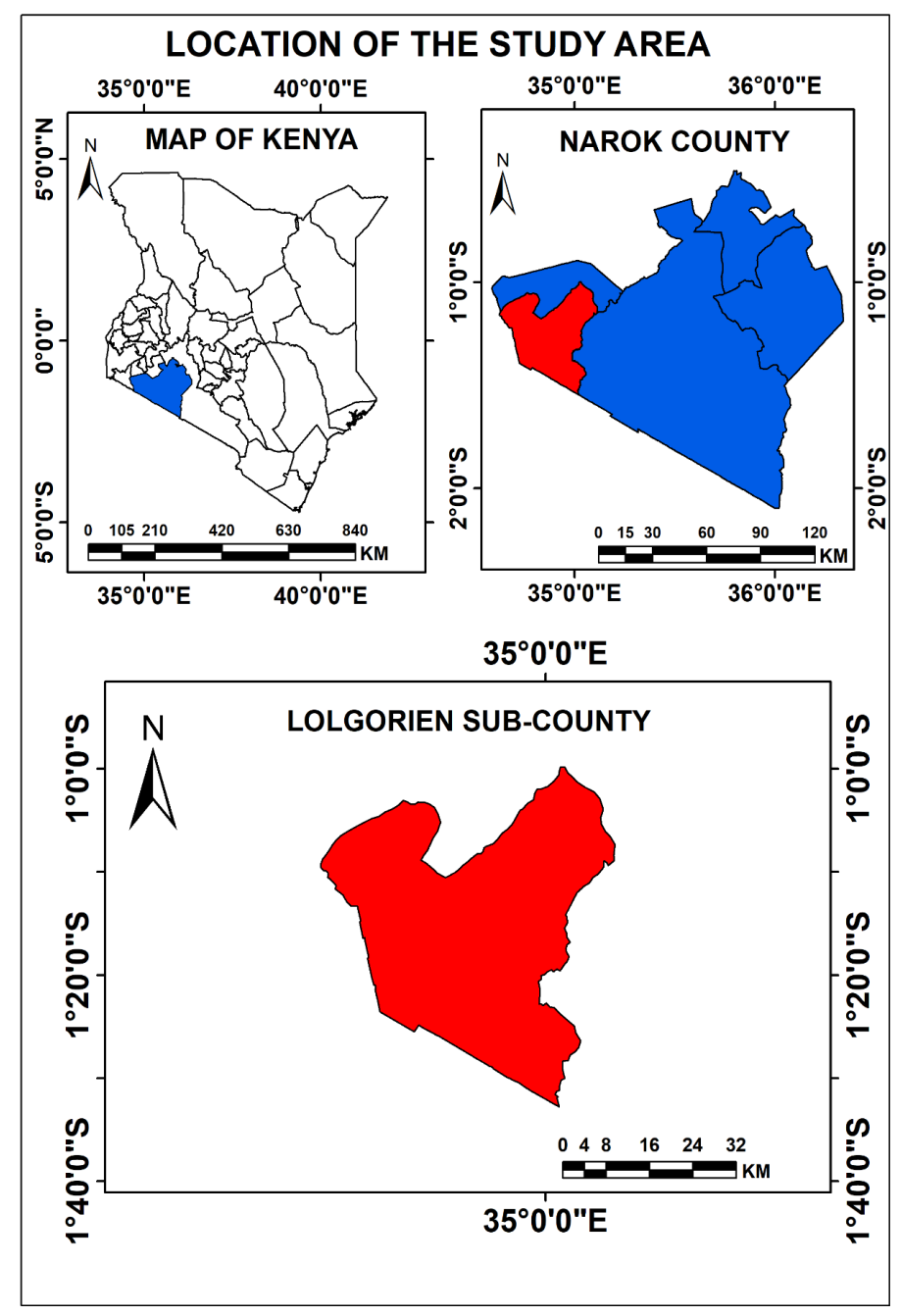

Fig 1. Location of Lolgorien with respect to Kenya 


\subsection{Geological setting}

Lolgorien is located within the Archean geological system of the Western Kenya. This geological system often consists of Nyanzian and Kavirondian units which are part of the larger Tanzanian craton and are considered to be the oldest rocks in Kenya ${ }^{(20)}$. Kavirondian systems which rest on top of Nyanzian system mainly consist of greywackes, grits, conglomorates and sandstones. The Nyanzian system is mainly composed of lavas, pyroclastics, banded iron formations as well as minor sediments. It mainly consists of the basalts, cherts, iron stones (banded iron formation) and shales ${ }^{(20)}$. These systems (Nyanzian and Kavirondian) are isoclinally folded and their axes generally trend in the East-West direction ${ }^{(20)}$. These two rock systems are generally intruded by several granitic and batholith intrusions. It is important to note that Tanzanian craton which hosts Nyanzian and Kavirodian systems is generally associated with precious and base metal mineralisation ${ }^{(20)}$. As such, metallic minerals such as copper, gold and silver have been reported in the area ${ }^{(20)}$. The geology map of lolgorien is shown in Figure 2.
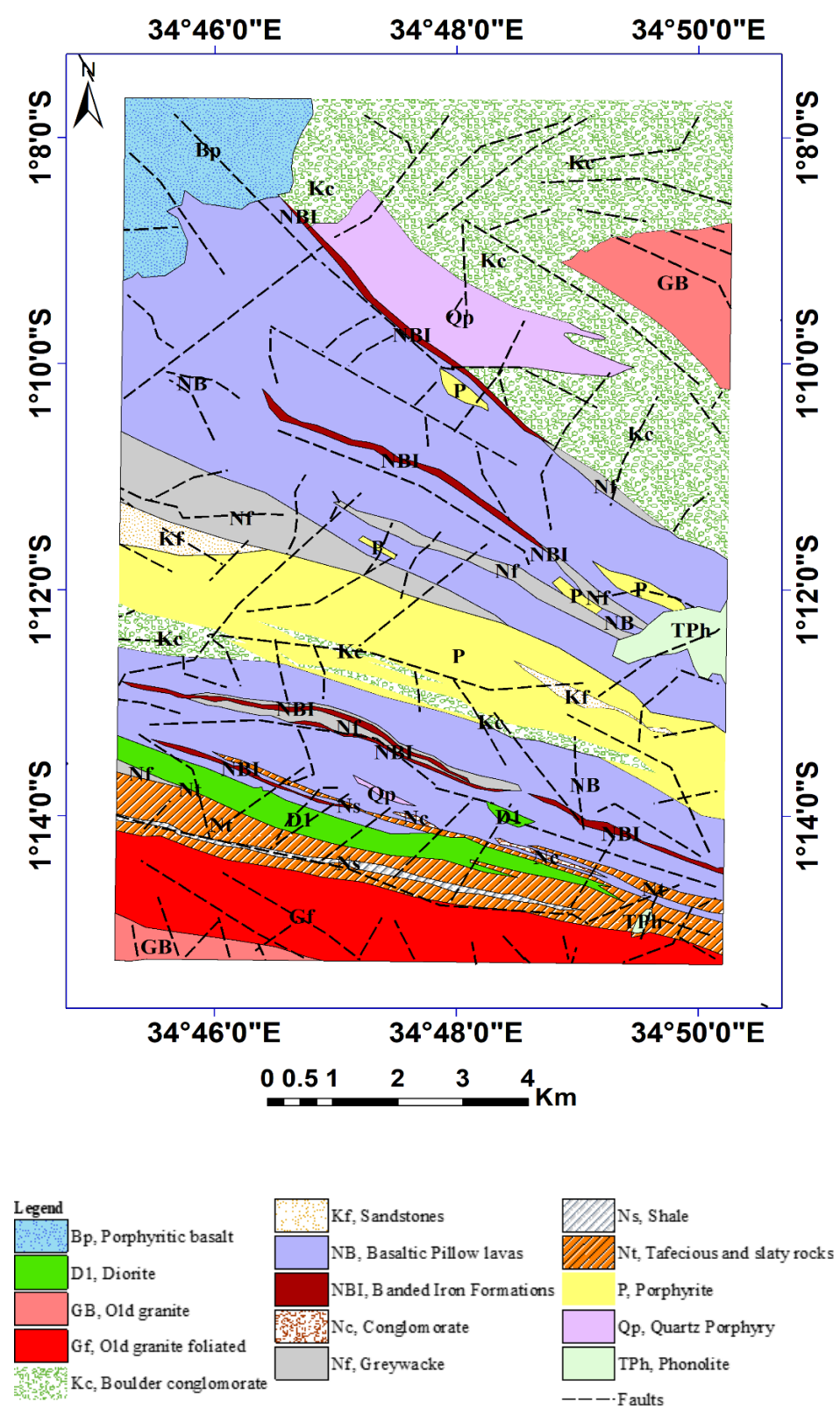

Fig 2. Geological map of Lolgorien (modified after Shackleton ${ }^{(19)}$ ) 


\subsection{Materials and methods}

\subsubsection{Data collection}

Two Landsat 8 (OLI) multispectral images were used in mapping hydrothermal alteration zones (areas of possible gold mineralisatiom) in Lolgorien. The two Landsat 8 (OLI) multispectral packages downloaded are:

1. LC08_L1TP_169061_20190920_20190926_01_T1 (Path 169 and Row 61 acquired on $20^{\text {th }}$ September, 2019)

2. LC08_L1TP_170061_20190810_20190820_01_T1 (Path 170 row 61 acquired on $20^{\text {th }}$ August, 2019).

Each of the two packages consisted of 11 bands images in form of GeoTIFF files, 1 metadata file (in form of ASCII file) and 1 quality assessment band image in form of GeoTIFF image. The projection of the downloaded Landsat 8 images is UTM zone $36 \mathrm{~S}$ and the datum is WGS 84. These images were downloaded via the Earth Explorer which is an interface that allows access to the United States Geological Society (USGS) which is remote sensing database where Landsat and other remote sensed data are archived. Of the 11 bands included in each of the downloaded package, the visible, NIR and SWIR bands were of particular interest. Specifically, the following bands were of particular interest in this study: band 2 to 7 . These are the most appropriate Landsat 8 bands for mineral exploration mapping, according to ${ }^{(21)}$.

Other than Landsat images, Shuttle Radar Topography Mission (SRTM) Digital Elevation Model (DEM) data with resolution of $30 \mathrm{~m}$ was also used in the study. It was used in mapping of the geological lineaments that may be found in the study area. SRTM DEM image had an identification of number (ID) as SRTM1S02E034V3 and a resolution of 1-ARC second (30 m). It was acquired on 27th August, 2020 from United States Geological Survey (USGS) website.

\subsubsection{Data processing}

In order to ensure that geolocal features captured by the satellites are enhanced and can be correctly identified, the downloaded images were processed using the following enhancement techniques:

1. Band rationing

2. Band compositing

3. Principal Component Analysis.

4. Hill shade processing

\section{Band compositing (band combination)}

The following band combinations were used: 4,2,3 (True colour image); 5,4,3 (False colour image); 7,5,2 and 5,6,7. These band composites are shown in Figure 3. When composite image is created using a combination of 3 bands (such as infrared bands or infrared bands and visible bands) in RGB, an image that is produced tends to enhance certain features ${ }^{(22)}$. This, however, depends on the bands selected for compositing. These bands are often assigned using the rocks' or altered minerals' spectral characteristics. The band combination for identification of altered minerals, according to ${ }^{(6,21)}$, are: RGB $(5,6,7)$, RGB $(7,5,2)$ and RGB $(5,4,3)$. It is for this reason that these band combinations were used to discriminate hydrothermally altered zones within the study area. The results for band combination are shown in Figure 3.

\section{Band rationing}

Band rationing is satellite image transformation technique where digital value (also known as the brightness values) of one particular band is divided by that of another band ${ }^{(23)}$. This technique of band combination, according to ${ }^{(23)}$, enhances as well as improves the compositional information of a satellite image while at the same time suppressing information that may not be useful. An example of such information (suppressed information) is shadowing caused by the topography. This allows for identification of the features that may not be seen in the unprocessed data. There exists several band ratios and false colour composites associated with these band ratios that have been proposed for enhancing alteration zones and lithological features. For instance, for Landsat 7 ETM+, band ratio 3/1 was suggested for discriminating iron oxides, and band ratio 5/7 has been suggested for discriminating hydroxyl-bearing minerals. For landsat 8 OLI, band ratios and band combination of 4/2, 6/7, 6/5 and $7 / 5$ in RGB are essential in discriminating lithological units, altered rocks and vegetation ${ }^{(21)}$. 
As such the following band ratios were used in this exercise

1. Band ratio $4 / 2$ was used to highlight iron oxide.

2. Band ratio $6 / 5$ was used to highlight ferrous minerals (iron bearing) other than iron oxides such as amphiboles, olivine and pyroxyne. This is because these minerals tend to have high adsorption in band 6 and reflectance on band 5 .

3. Band ratio $6 / 7$ was used to highlight hydroxyl bearing rocks.

4. Band ratio $7 / 5$ was used to highlight clay minerals.

The results of band ratios are shown in Figure 4.

In addition to band ratios, band ratio composites were also formed. The following band ratio composites were formed: Sabin's ratio (4/2, 6/7 and 6/5 in RGB) which was used to map hydrothermal alteration and in mapping of the lithological features; Kaufmann's ratio $(7 / 5 ; 5 / 4 ; 6 / 7)$ which was used to discriminate altered rocks and lithological units from the vegetation; and composite band ratio 4/2,6/7, 5 in RGB which was also used to discriminate altered rocks and outcrops from vegetation. The results of band ratio composites are shown are in Figure 5.

\section{Principle component analysis}

The density of the vegetation plays a major role in the detection as well as mapping of the hydrothermally altered rocks using band rationing. In order to minimise the effects of vegetation, a spectral unmixing technique known as principal component analysis was employed in this study ${ }^{(24)}$. Process of principal component analysis was begun by carrying out the component principle analysis on six landsat 8 bands, namely: band 2, band 3, band 4, band 5, band 6 and band 7 . The results of this analyis are shown in Tables 1 and 2 (eigen vector matrix output) and Figure $6 \mathrm{~A}$ and B. The results in Tables 1 and 2 identify the principal components (PCs) that contain the most useful spectral information.

\section{Hillshade analysis}

Shuttle Radar Topography Mission (SRTM) Digital Elevation Model (DEM) image was analysed using hillshade technique ( $315^{\circ}$ azimuth and $45^{\circ}$ dip) to discriminate the lineaments from other relief features. From the hillshade image, lineaments were extracted manually and results are shown in Figure 7A and B.

\section{Results}

\subsection{Band combination}

The results of the various band combinations are shown in Figure 3. The Figure $3 \mathrm{~A}$ is true colour image created by combining bands 4, 3 and 2 in RGB. Green colour represents vegetation and dark brown colour represents exposed areas. Whitish colour represents buildings. Figure 3B is a false colour image created by combining bands 5, 4 and 3 in RGB. Brown and grey colours represent outcrops (exposed areas), whitish colour represents areas with houses (areas occupied by people), and red colour represents vegetation. Figure $3 \mathrm{C}$ is a composite of bands 7, 5 and 2. Orange (Brown) colours represent outcrops, black colour represents water (river) and green colour represents vegetation. Figure 3D is a composite of Band 5, band 6 and band 7. Light blue colour represents exposed surfaces, black colour represents water bodies, hydrothermally altered rocks were represented by blue colour, and vegetation is represented by brown and orange colours. 

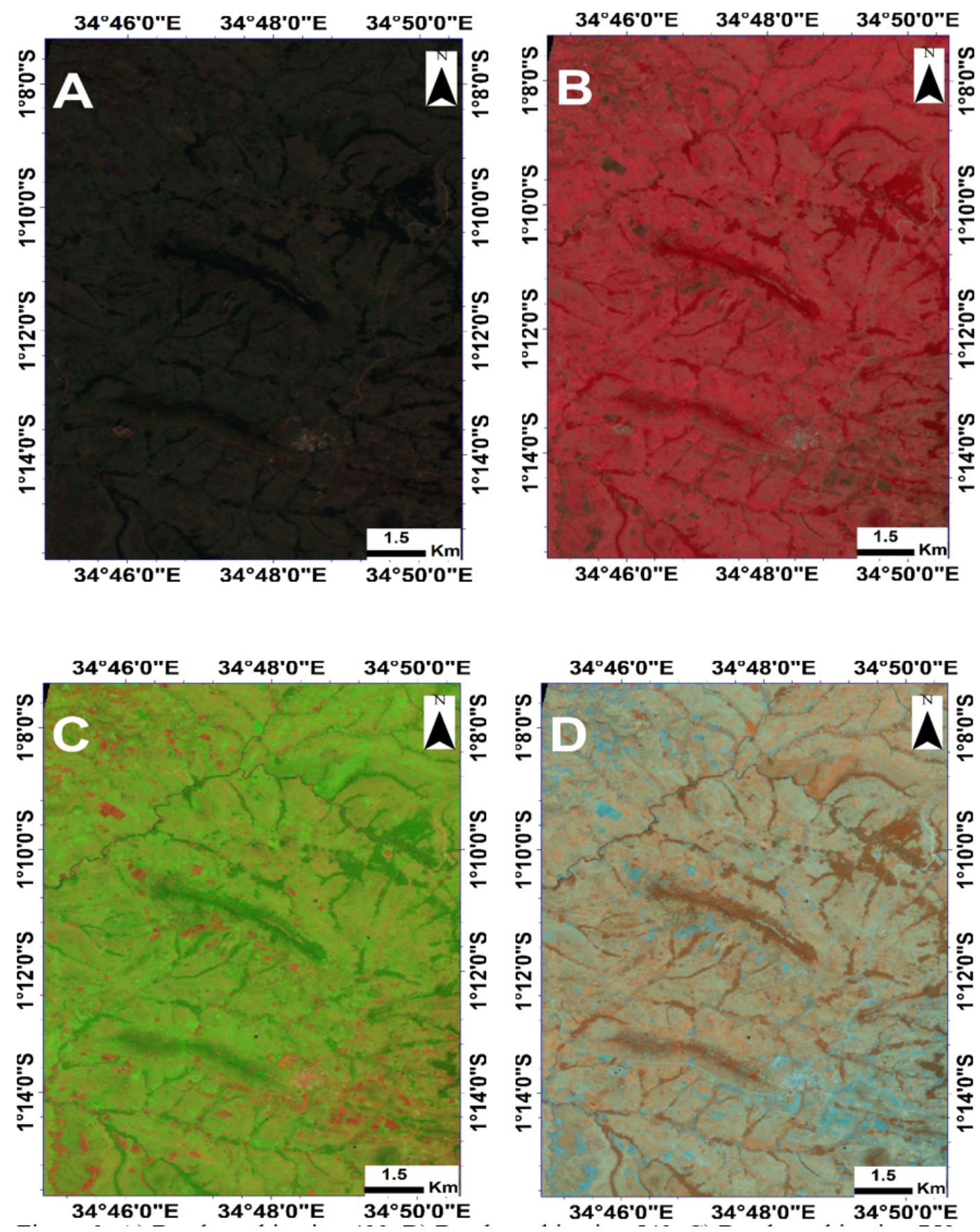

Fig 3. A) Band combination 423. B) Band combination 543. C) Band combination 752. Band combination 567.

\subsection{Band ratio}

The results of band ratio are shown in Figure 4. The Figure 4A is band ratio 4/2. This band ratio does not clearly discriminated areas of interest. Figure $4 \mathrm{~B}$ is band ratio $6 / 5$; Figure $4 \mathrm{C}$ is band ratio $6 / 7$; and Figure $4 \mathrm{D}$ is band ratio $7 / 5$. The bright tones (whitish regions) in $\mathrm{B}$ and $\mathrm{D}$, and darker tones in $\mathrm{C}$ represent areas with potential of having minerals associated with hydrothermal alteration such as clay minerals such as montmorillonite, kaolinite and illite, and iron oxides. 

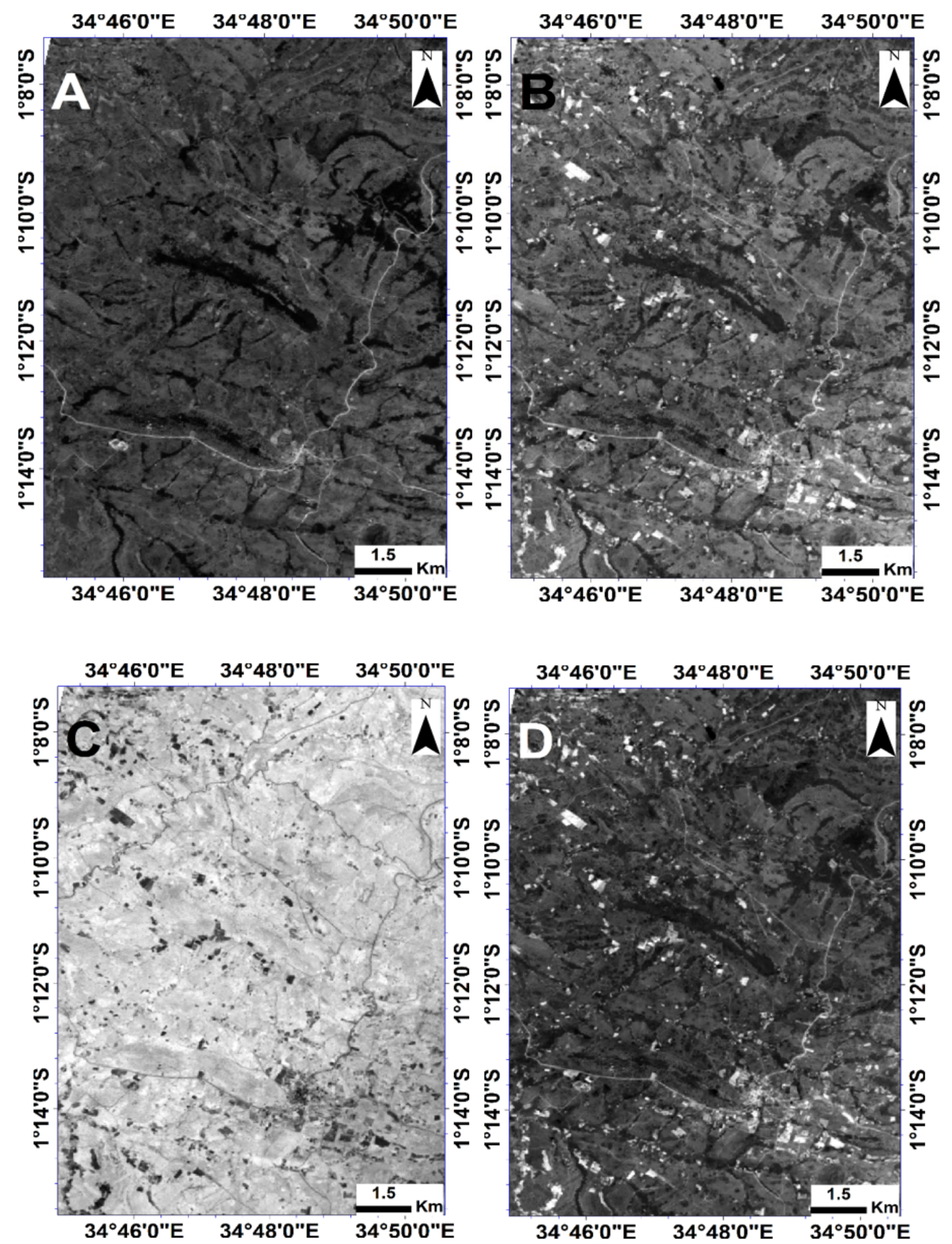

Fig 4. A) Band ratio 4/2. B) Band ratio 6/5. C) Band ratio 6/7. D) Band ratio 7/5.

\subsection{Band ratio composite (Sabin's ratio and Kaufmann's ratio)}

The results of band ratio composite are shown in Figure 5. The results show that Sabin's ratio (Figure 5A) and 4/2, 6/7, 5 composite band ratios (Figure 5C) were able to discriminate areas associated with outcrops from the vegetation. In Sabin's ratio (Figure 5A), outcrops (hydrothermally altered outcrops) are shown in blue, vegetation is highlighted in green and water bodies in black. In composite of 4/2, 6/7, 5 in RGB (Figure 5C), the areas associated with hydrothermally altered rock outcrops are shown in reddish brown colour, vegetation is shown in green colour (both light and dark), and water bodies by black pixels. Kaufmann's ratio (Figure 5B) showed that these outcrops are probably associated with hydrothermally alternated units. In this 
composite $(7 / 5,5 / 4,6 / 4$ in $\mathrm{RGB})$ and as shown in Figure 5B), rose colour (violet) represent areas that are probably associated with outcrops associated with granite or basalt as these rocks are often associated with amphibole, olivine and pyroxene; black represents water bodies (in this case rivers), red represents areas probably associated with iron oxides, and light blue represent vegetation.
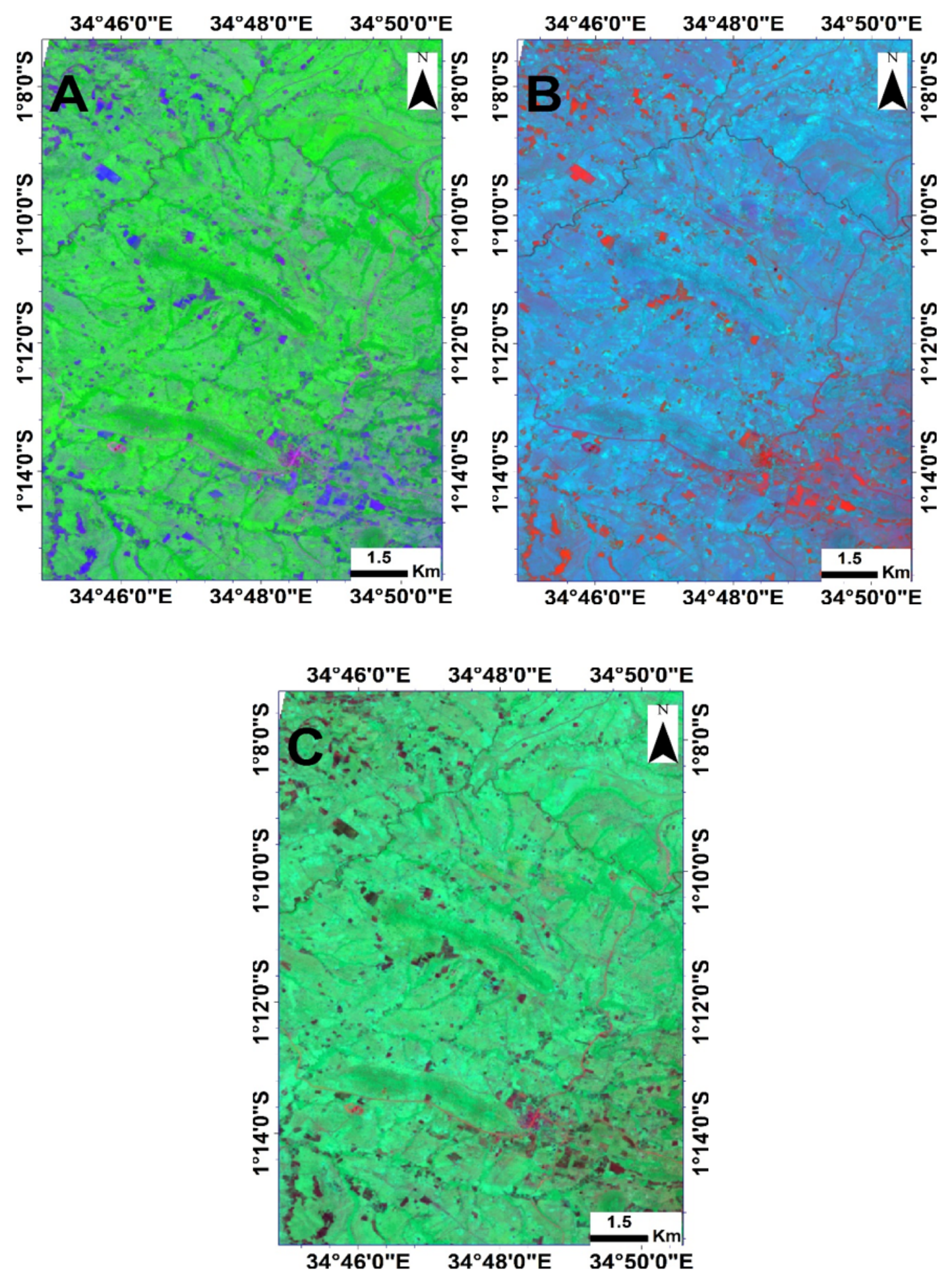

Fig 5. A) 4/2, 6/7,65 (Sabin's ratio). B) 7/5,5/4,6/7 (Kaufmann's ratio). C) Band ratio composite 4/2,6/7,5. 


\subsection{Principal component analysis}

To highlight or discriminate hydrothermally altered rocks and other minerals from vegetation, bands 1, 2, 3, 4, 5 and 6 were processed using principal component analysis. The Eigen values and Eigen vectors associated with this analysis are shown in Table 1.

Table 1. Principle components Eigen values and Eigen vectors

\begin{tabular}{lllllll}
\hline & PC1 & PC2 & PC3 & PC4 & PC5 & PC6 \\
\hline Band 2 & 0.31493 & 0.14391 & -0.45739 & -0.214 & 0.62052 & 0.48996 \\
Band 3 & 0.31438 & 0.1236 & -0.4226 & -0.10466 & 0.11661 & -0.82628 \\
Band 4 & 0.33255 & -0.04044 & -0.52852 & 0.13162 & -0.71887 & 0.27267 \\
Band 5 & 0.49381 & 0.72266 & 0.42106 & 0.22504 & -0.06424 & 0.04306 \\
Band 6 & 0.51819 & -0.3826 & 0.37664 & -0.65268 & -0.13081 & 0.01151 \\
Band 7 & 0.42312 & -0.54199 & 0.11715 & 0.67029 & 0.25168 & -0.02939 \\
Eigen values & 253758632 & 7346384.854 & 4374677 & 194295.8 & 185919 & 16683.31 \\
Percentage of Eigen values & 95.4423 & 2.7631 & 1.6454 & 0.0731 & 0.0699 & 0.0063 \\
Cumulative percentage of Eigen & 95.4423 & 98.2053 & 99.8507 & 99.9238 & 99.9937 & 100 \\
values & & & & & & \\
\hline
\end{tabular}

From the Table 1 it is observed that PC1, PC2 and PC3 contain more than $99.85 \%$ of the data variance. They were, therefore, combined in an RGB composite to yield principal component image shown in Figure 6A. From the figure, the green colour in the figure represents vegetation; and blue colour represents hydrothermal alteration rocks.

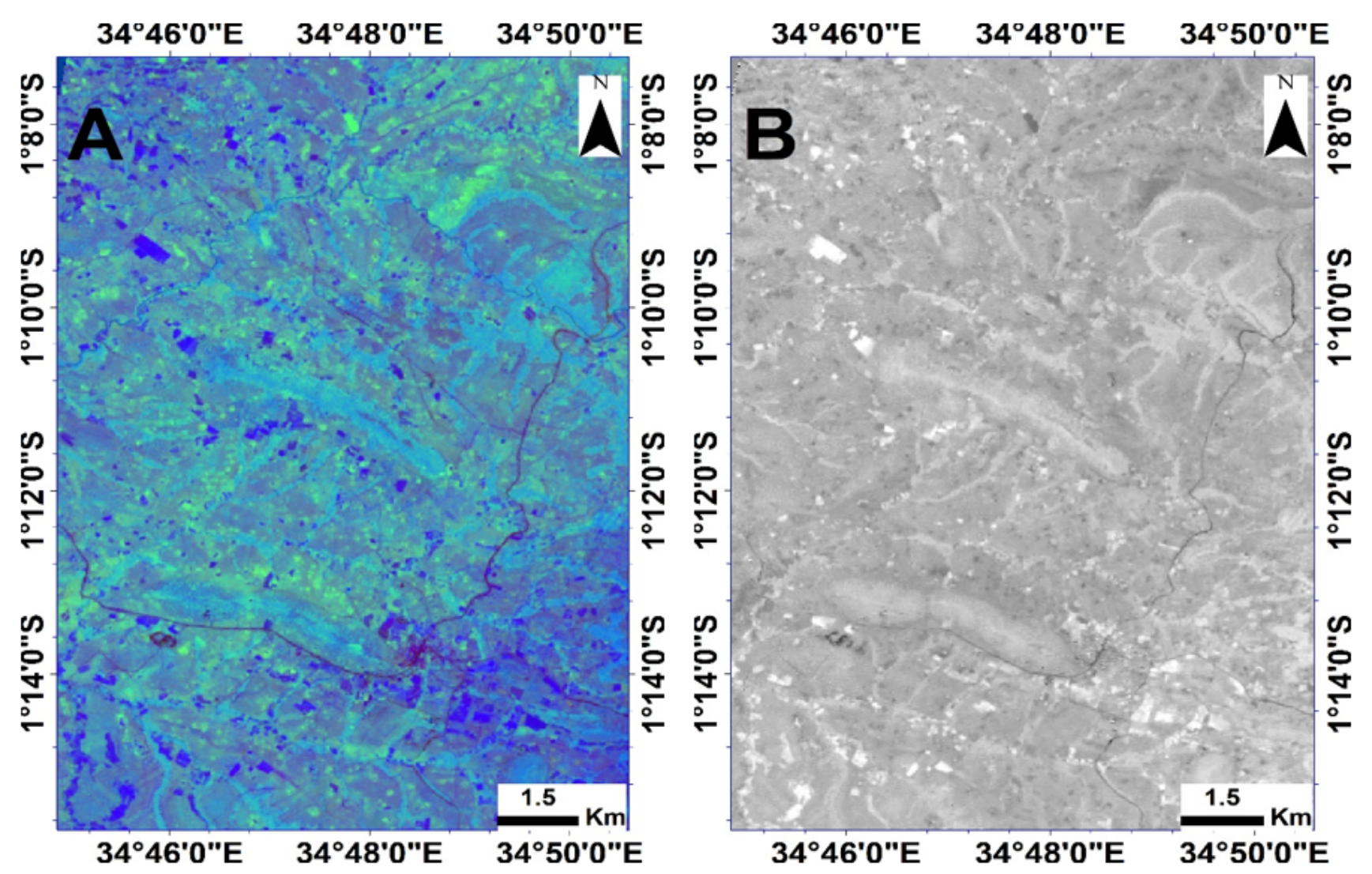

Fig 6. A) The RGB combination of PC1, PC2 and PC 3 components. The green colour in the figure represents vegation; dark blue represents hydrothermally alteratered rocks. B) Principle component 4 (PC4). The bright pixels represent hydrothermally altered rocks. 
To enhance the findings of the principal component analysis, band 2, band 4, band 5 and band 6 of Landsat 8 were also subjected to principal component analysis. This was done to highlight areas associated with iron oxides from the vegetation. The eigen values and vectors are as shown in Table 2. The results are shown in Figure 6B.

Table 2. Principle components Eigen values and Eigen vectors for principle components for bands 2, 4, 5 and 6.

\begin{tabular}{lllll}
\hline & PC1 & PC2 & PC3 & PC4 \\
\hline Band 2 & 0.36989 & -0.08588 & -0.56344 & 0.73372 \\
Band 4 & 0.38882 & -0.32765 & -0.55363 & -0.65951 \\
Band 5 & 0.58727 & 0.79318 & 0.09668 & -0.12898 \\
Band 6 & 0.6059 & -0.50611 & 0.60554 & 0.10032 \\
Eigen values & $1.84 \mathrm{E}+08$ & 4947739 & 3316029 & 181736 \\
Percentage of Eigen values & 95.6045 & 2.5751 & 1.7259 & 0.0946 \\
Cumulative percentage of Eigen values & 95.6045 & 98.1796 & 99.9054 & 100 \\
\hline
\end{tabular}

From the Table 2 it is observed that PC4 contains $0.09 \%$ of the total variance data, and it shows the highest positive Eigen vector value loading for band 2 (0.73372) and the highest negative Eigen vector value in band $4(-0.65951)$. Generally, minerals associated with iron oxides have low reflectance ranging between $0.45-0.51 \mu \mathrm{m}$ (range of band 2 ) and low absorption ranging between $0.64-0.67 \mu \mathrm{m}$ (band 4 range). Therefore, in these two bands (band 2 and band 4 ) pixels associated with iron oxides are often bright in the PC4 image as shown in Figure 6B.

\subsection{Lineament extraction}

Lineaments in the study were extracted using hillshade analysis of the SRTM-DEM image of the study area. The extracted lineaments are shown in Figure 7A and B. Figure 7A is the lineaments plus hillshade map of the area of the study. Figure 7 B is lineament density map. Figure 7C is the rose diagram of the identified lineaments. From the figures it is observed that there is higher density of lineaments in the southern and South Eastern part of Lolgorien which happen to the same areas associated with iron oxides and other hydrothermally altered rocks. Rose diagram (Figure 7C) show that most of the lineaments trend in the NW-SE direction which is the same trend as the lithological units found in the study area.

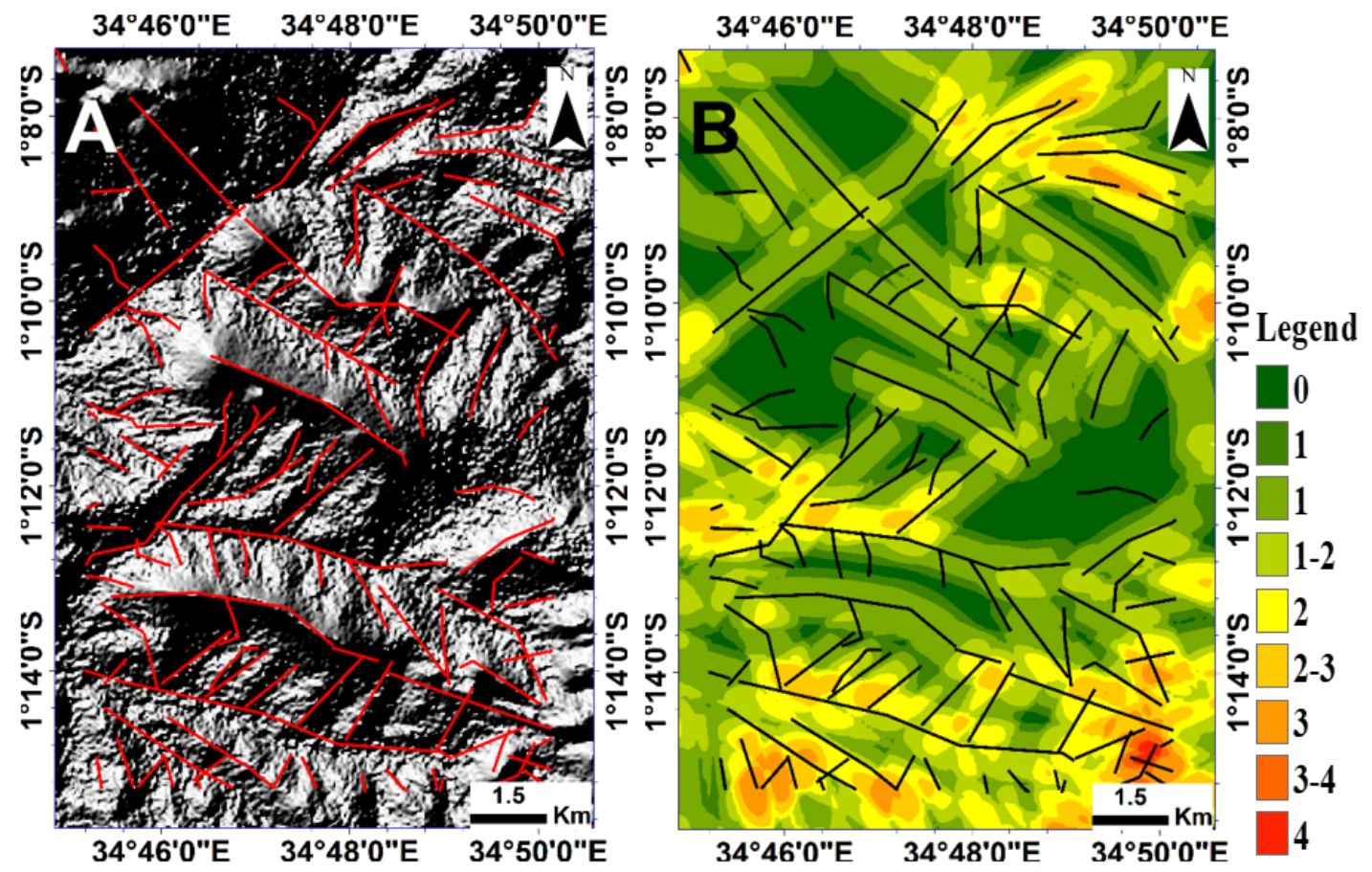




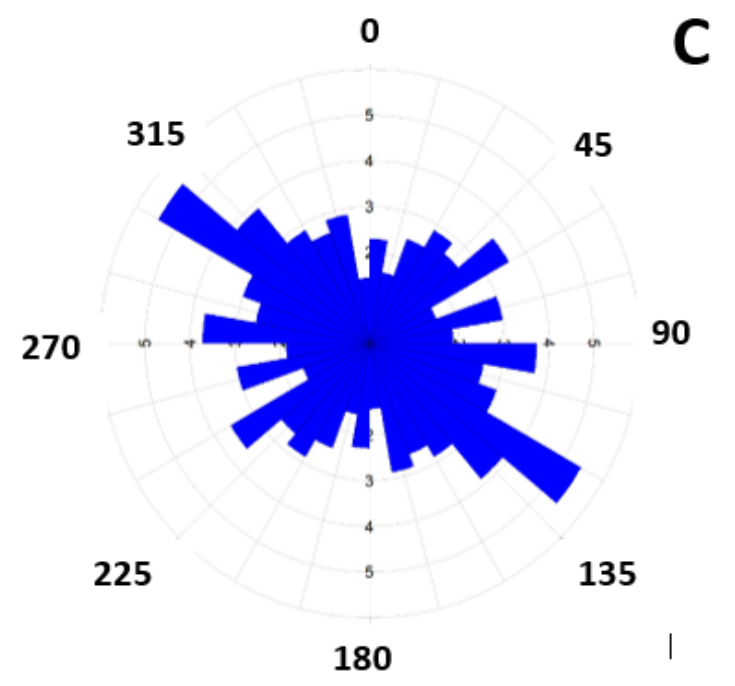

Fig 7. A) Extracted lineaments superimposed on the hillshade mape of the study area. B) Lineament density map of the study area. C) Lineament rose diagram

\section{Discussion}

Lolgorien area is generally covered by vegetation (some areas with thick vegetation and others with light vegetation) making it difficult to map geological features and contact zones (geological boundaries) associated with lithological units using remote sensed images especially the Landsat images (Landsat 8). Examples of regions covered by thick forests and light vegetation are shown in Figure $8 \mathrm{~A}$ and B respectively. Even though the area is covered by both light and thick vegetation which make it difficult to map geological boundaries using Landsat images, the remote sensing exercise was successfully used to map lineaments and areas associated with hydrothermal alterations (especially the clay minerals and iron oxides).
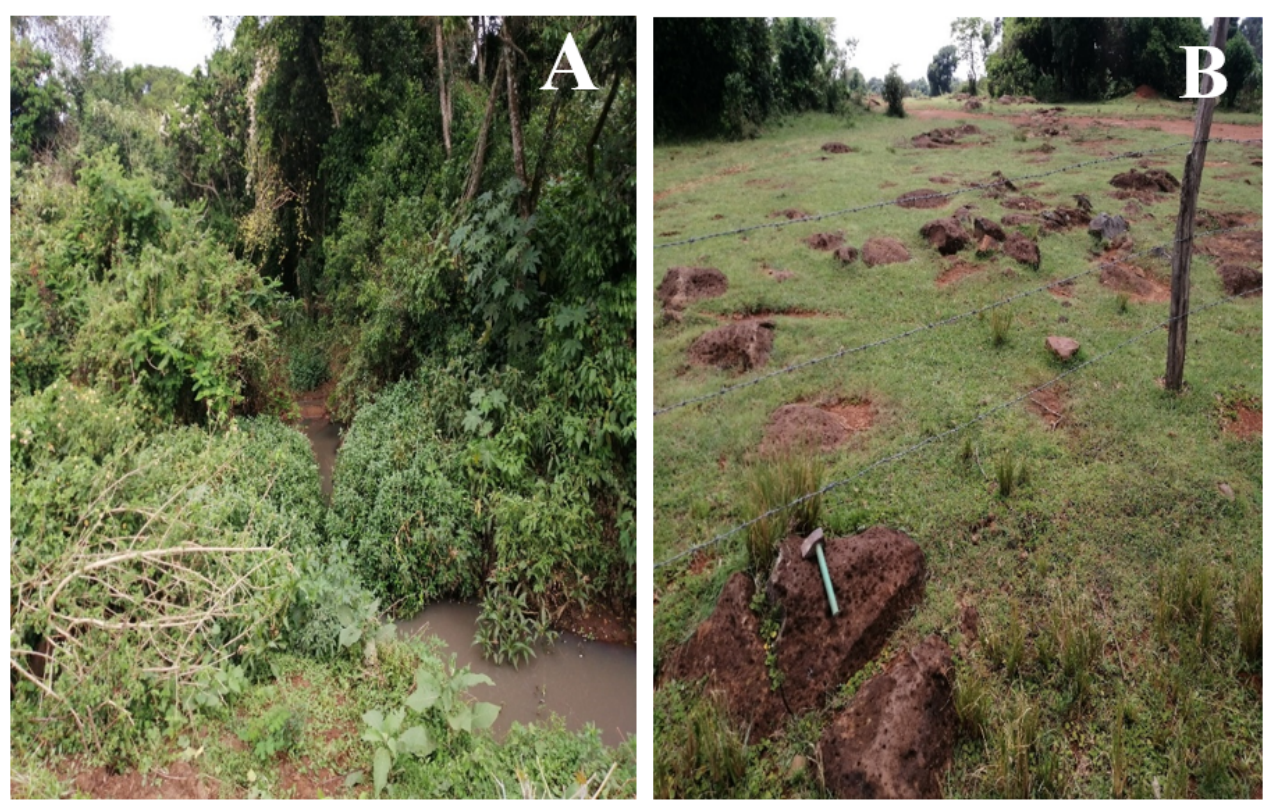

Fig 8. A) Image of stream in Lolgorien area showing thick vegetation cover. The image was taken at coordinates 9857990, 701114. B) An image showing exposed basalts covered by light vegetation. The image was captured at coordinates: 9862739, 706561. 


\subsection{Band ratio compositing in mapping of outcrops and iron oxides}

A number of techniques were used to successfully to map outcrops and hydrothermal alteration zones especially those associated with iron oxides, ferrous minerals (minerals associated with iron ions such as amphibole, olivine and pyroxene other than iron oxides) and clay minerals. One of the techniques used as already discussed in the results sections is composite band rationing (Sabin's ratio, Kaufmann ratio and 4/2, 6/7, 5 in RGB band composite). The results of these composite band ratios are similar. They are shown in Figure 5. As shown in Figure 5, Sabin's ratio (Figure 5A), hydrothermally altered outcrops are shown in blue, vegetation is highlighted in green and water bodies in black. In composite of 4/2, 6/7, 5 (Figure 5 C), hydrothermally altered rock outcrops are shown in reddish brown, vegetation is shown in green colour and water bodies by black pixels. In Kaufmann's ratio (Figure $5 \mathrm{~B}$ ), rose colour (violet) represent areas that are probably associated with outcrops associated with granite or basalt as these rocks are often associated with amphibole, olivine and pyroxene; black represents water bodies (in this case rivers), red represents areas probably associated with iron oxides, and light blue represent vegetation.

A field observation (ground truthing) and geological map confirmed the results of these composite. For instance, the lower part (southern) part of the study area is dominated by granite outcrops (see geological map of Lolorien in Figure 2). The areas around the Lolgorien hill and the South Eastern part of the study area are associated with banded iron formations (which are iron oxides) enclosed in basaltic formations. Figure 9A shows an example of granite outcrops found in the southern part of the study area while Figure 9B as an example of banded iron formations rocks found in the areas around the Lolgorien hill.

The technique of discriminating outcrops from the vegetation using band composites has been employed by other studies too. In ${ }^{(21)}$, band ratio composites were used to discriminate outcrops in Chaves area (Portugal) using Landsat 8 images.
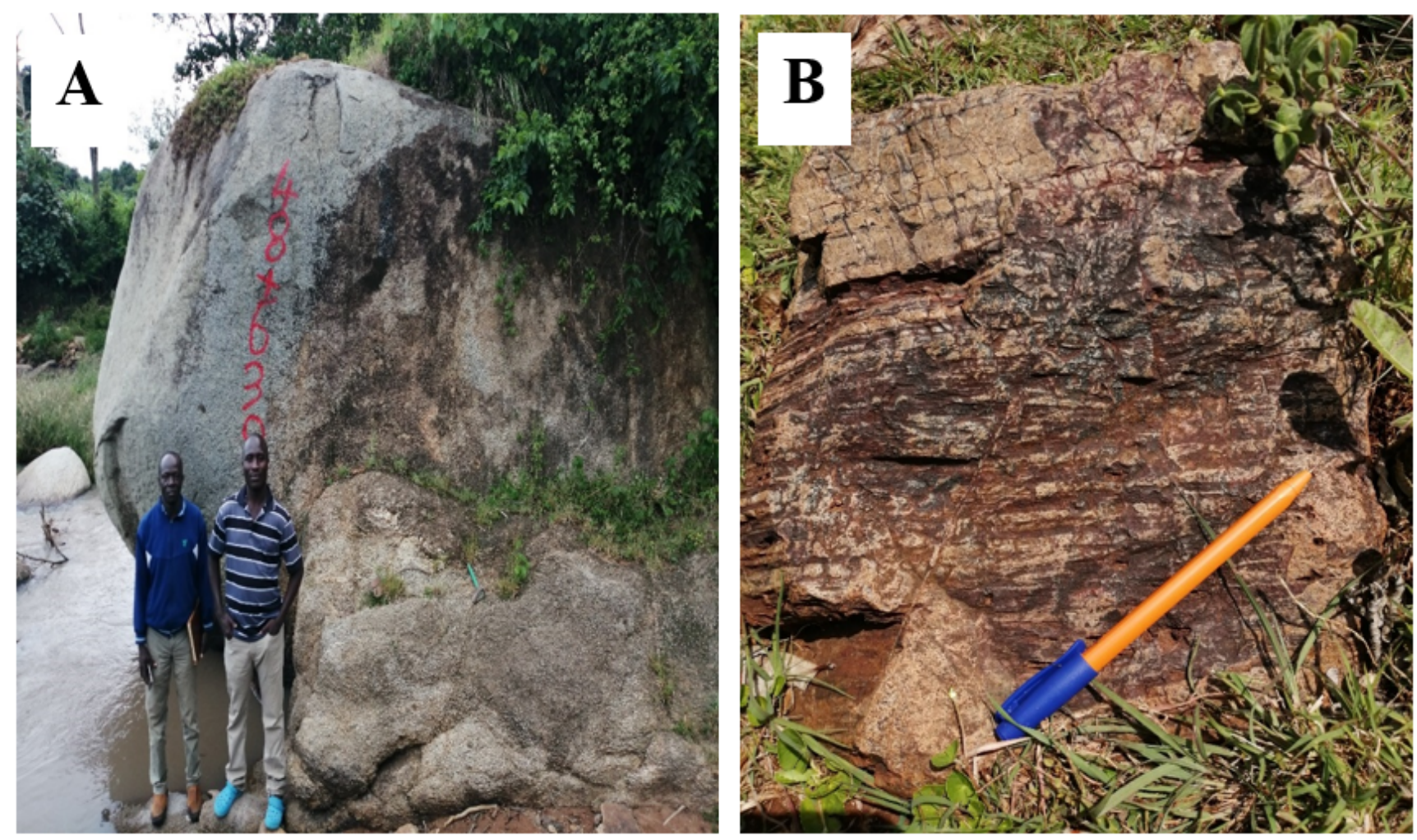

Fig 9. A) A granite outcrop in the southern part of the study area. The outcrop is located at coordinates 9857992, 7011055. Kaufamann's band ratio composite was able to accurately locate granite outcrops plus other outcrops within the area of study. B) Banded iron formation (an example of iron oxide) found at Lolgorien hill. Iron oxides were discriminated accurately using Kaufamann's band ratio composite. The outcrop is located at coordinates $9864655,697146$.

The use of band ratio composites such as Kaufamann's composite to map hydrothermal alteration rocks and granites has been applied by previous studies. Authors in ${ }^{(3)}$ used Kaufamann's composite to map hydrothermal alteration zones and granites in Roodepoort and Westonaria in Gauteng Province and Witbank and Kriel in Mpumalanga Province, all of which are located in South Africa. 


\subsection{Mapping clay minerals and iron oxides using band ratios}

Band ratios were able discriminate areas associated iron oxides, ferrous minerals (other than iron oxide such as amphibole, olivine and pyroxene) and clay minerals. In the band ratios $4 / 2,6 / 7,6 / 5$, and $7 / 5$ as shown in Figure $4 \mathrm{~A}, \mathrm{~B}, \mathrm{C}$ and $\mathrm{D}$ respectively, the brighter pixels in Figure $4 \mathrm{~B}$ and $\mathrm{D}$ and darker tones in $\mathrm{C}$ represent areas with possibility of having minerals associated with hydrothermal alteration such as clay minerals (montmorillonite, kaolinite and illite) and iron oxides. Band ratio $6 / 5$ highlighted areas with abundant ferrous minerals (other than iron oxides) in bright pixels as shown in Figure 4C. The band 7/5 discriminated areas with potential of rocks associated with clay minerals such as kaolinite, illite and montmorillonite as shown in Figure 4D. Band ratio 6/7 discriminated areas that possibly have altered rocks associated with alunite and clays (Figure 4B). The ground truthing exercise (field observations) proved this as shown in Figure 9B. The figure is an outcrop of banded iron formation (which is associated with iron oxides) found around Lolgorien hill.

The band ratio composite approach has been used in the past to discriminate hydrothermally altered rocks in heavily vegetated area. One such study was conducted by ${ }^{(25)}$ which was conducted in Baguio district in Philippines using Landsat Thematic Mapper (TM) images as well as ground mapping. The study found that the brighter pixels found in band ratio analyses were associated with hydrothermal alterations. Another study that employed band ratios 4/2, 6/7 and 6/5 in mapping hydrothermally altered rocks was the study by ${ }^{(26)}$ which was carried out on Landsat 8 images in Ariab Mining District, Red Sea hills, Sudan. In ${ }^{(26)}$, the brighter pixels associated with these band ratios discriminated areas of possible hydrothermal alterations such as areas of iron oxides, ferrous minerals and clay minerals. Authors in ${ }^{(5)}$ also used band ratios to successfully delineate areas with iron bearing minerals (especially ferric and ferrous oxides) in Wadi Allaqi area, South Eastern Desert of Egypt. In ${ }^{(6)}$, band ratios were used to discriminate areas with potential of iron-based minerals in Sar Cheshmeh copper mining district, south-eastern Islamic Republic of Iran using Landsat 8 (OLI) images. In this study, the band ratios with bright pixels delineated areas with potential of iron bearing minerals.

\subsection{Mapping of outcrops using band combination}

The band combinations were mainly used to discriminate areas covered by the outcrops from the those covered by vegetation and water. Band combinations: 7,5,2; 5,6,7; 5,4,3; and 4,3,2 were used in this case. The results are shown in Figure 3 (A to D). In all these 4 band combinations, rock outcrops and exposed surfaces were successfully discriminated from the vegetation and water bodies (rivers in this case). The use of band combination to discriminate rock outcrops has been employed in the previous studies. One such study was conducted by ${ }^{(21)}$ who used the above band combinations to discriminate rock outcrops from thick vegetation in Chaves license, Portugal. A similar study was carried out by ${ }^{(27)}$ who used band combinations on Landsat 8 imagery to delineate rock outcrops from clouds, sea and snow in Antarctica. In ${ }^{(28)}$, band combinations were also used on Landsat 8 OLI data (the same band combinations as the ones used in this study) to successfully delineate hydrothermally altered rocks and rock outcrops at Singhbhum Shear Zone in East India.

\subsection{Mapping of hydrothermal alteration zones using principal component analysis}

To further delineate areas associated with iron oxides and hydrothermal alteration zones, principal component analysis was carried. This analysis was applied because it minimizes the effect of vegetation. The results are shown in Tables 1 and 2 and Figure 6. As shown in Figure 6A and B, the hydrothermal alteration zones are shown by bright pixels in Figure 6B and blue pixels in Figure 6A. The use of principal component analysis in identification of areas that may associated with hydrothermal alteration and iron oxides has been carried out before. A study by ${ }^{(21)}$ used this technique to successfully delineate hydrothermal zones in Chaves license, Portugal.

\subsection{Relationship between hydrothermal alteration and lineaments occurrence}

From the lineament maps shown in Figure $7 \mathrm{~A}$ and B, it is observed that areas identified as possible hosts of minerals associated with hydrothermal alteration have large number of lineaments. This is because lineaments (especially faults) are potential pathways through which mineralised fluids (hydrothermal fluids) migrate and alter or mineralise the adjacent wall rock or form mineralised veins. As such, areas with high density of lineaments are most likely associated with hydrothermally altered rocks. 


\section{Conclusion}

Despite the study area covered by thick vegetation, processing of Landsat 8 (OLI) images using band ratio, band composite and principal component analysis, and processing of SRTM image using hillshade analysis were able to identify areas of possible hydrothermal alteration (areas that may be associated with clay minerals and iron oxides), and areas associated with high density of lineaments. These areas may be related to Lolgorien's gold mineralisation. The areas are mainly located in the Southern, South Eastern, Central and North Western part of the study area. These were confirmed by field work as exposed banded iron formations were found in a number of locations especially the Southern and South-Eastern part of Lolgorien. The study also found that areas with possibility of hydrothermal alteration (the identified areas) are also associated with relatively large number of faults. Coincidentally, these areas are also associated with numerous abandoned artisanal mines proving the fact that indeed gold mineralisation may be found in these places. It was also noted that even though Central and North-Western parts of Lolgorien had similar geological properties (in terms of lineament density and hydrothermal alteration) as the Southern and South-Eastern parts, these zones (Central and North-Western parts) have never been exploited for gold or other minerals. It is, therefore, recommended that future studies consider geochemical and geophysical characterisation of these zones ascertain the presence of these minerals. It is important to note that due to thick vegetation cover, mapping of different types of lithological units found in Lolgorien was not possible.

\section{Acknowledgments}

This manuscript is part of the first author's Ph.D. work and was funded by the African Union through the Pan-African University, Life and Earth Sciences Institute (including Health and Agriculture), University of Ibadan, Nigeria (PAULESI).

\section{References}

1) Kotnise G, Chennabasappa S. Application of remote sensing techniques in identification of lithological rock units in southern extension of Kolar Schist Belt from Chigargunta. International Journal of Innovative Science, Engineering \& Technology. 2015;2(11).

2) Drews-Armitage SP, Romberger SB, Whitney CG. Clay alteration and gold deposition in the Genesis and Blue Star deposits, Eureka County, Nevada. Economic Geology. 1996;91(8):1383-1393. Available from: https://dx.doi.org/10.2113/gsecongeo.91.8.1383.

3) Mahboob MA, Genc B, Celik T, Ali S, Atif I. Mapping hydrothermal minerals using remotely sensed reflectance spectroscopy data from Landsat. Journal of the Southern African Institute of Mining and Metallurgy. 2019;119(3):249-89. Available from: https://dx.doi.org/10.17159/2411-9717/2019/v119n3a7.

4) Amara BN, Aissa DE, Maouche S, Braham M, Machane D, Guessoum N. Hydrothermal alteration mapping and structural features in the Guelma basin (Northeastern Algeria): contribution of Landsat-8 data. Arabian Journal of Geosciences. 2019;12(3):94-94. Available from: https://dx.doi.org/10.1007/ s12517-019-4224-4.

5) Eldosouky AM, Abdelkareem M, Elkhateeb SO. Integration of remote sensing and aeromagnetic data for mapping structural features and hydrothermal alteration zones in Wadi Allaqi area, South Eastern Desert of Egypt. Journal of African Earth Sciences. 2017;130:28-37. Available from: https: //dx.doi.org/10.1016/j.jafrearsci.2017.03.006.

6) Pour AB, Hashim M. Hydrothermal alteration mapping from Landsat-8 data, Sar Cheshmeh copper mining district, south-eastern Islamic Republic of Iran. Journal of Taibah University for Science. 2015;9(2):155-166. Available from: https://doi.org/10.1016/j.jafrearsci.2017.03.006.

7) Liu L, Li Y, Zhou J, Han L, Xu X. Gold-copper deposits in Wushitala, Southern Tianshan, Northwest China: Application of ASTER data for mineral exploration. Geological Journal. 2018;53:362-371. Available from: https://doi.org/10.1002/gj.2989.

8) Durand J. The impact of gold mining on the Witwatersrand on the rivers and karst system of Gauteng and North West Province, South Africa. Journal of African Earth Sciences. 2012;68:24-43. Available from: https://doi.org/10.1016/j.jafrearsci.2012.03.013.

9) Sutton MW. Use of remote sensing and GIS in a risk assessment of gold and uranium mine residue deposits and identification of vulnerable land use . 2013.

10) Sutton M, Weiersbye I, Galpin J, Heller D, Fourie A, Tibbett M. A GIS-based history of gold mine residue deposits and risk assessment of post-mining land uses on the Witwatersrand Basin, South Africa. In: Mine Closure 2006. 2006;p. 667-678.

11) Pour AB, Sekandari M, Rahmani O, Crispini L, Läufer A, Park Y, et al. Identification of Phyllosilicates in the Antarctic Environment Using ASTER Satellite Data: Case Study from the Mesa Range, Campbell and Priestley Glaciers, Northern Victoria Land. Remote Sensing. 2020;13(1). Available from: https://dx.doi.org/10.3390/rs13010038.

12) Pour AB, Park Y, Crispini L, Läufer A, Hong JK, Park TYS, et al. Mapping Listvenite Occurrences in the Damage Zones of Northern Victoria Land, Antarctica Using ASTER Satellite Remote Sensing Data. Remote Sensing. 2019;11(12). Available from: https://dx.doi.org/10.3390/rs11121408.

13) Sekandari M, Masoumi I, Pour AB, Muslim AM, Rahmani O, Hashim M, et al. Application of Landsat-8, Sentinel-2, ASTER and WorldView-3 Spectral Imagery for Exploration of Carbonate-Hosted Pb-Zn Deposits in the Central Iranian Terrane (CIT). Remote Sensing. 2020;12:1239-1239. Available from: https://dx.doi.org/10.3390/rs12081239.

14) Bolouki SM, Ramazi HR, Maghsoudi A, Pour AB, Sohrabi G. A Remote Sensing-Based Application of Bayesian Networks for Epithermal Gold Potential Mapping in Ahar-Arasbaran Area, NW Iran. Remote Sensing. 2019;12. Available from: https://dx.doi.org/10.3390/rs12010105.

15) Pour, Park, Park, Hong, Muslim, Läufer, et al. Landsat-8, Advanced Spaceborne Thermal Emission and Reflection Radiometer, and WorldView-3 Multispectral Satellite Imagery for Prospecting Copper-Gold Mineralization in the Northeastern Inglefield Mobile Belt (IMB), Northwest Greenland. Remote Sensing. 2019;11(20). Available from: https://dx.doi.org/10.3390/rs11202430.

16) Zoheir B, El-Wahed MA, Pour AB, Abdelnasser A. Orogenic Gold in Transpression and Transtension Zones: Field and Remote Sensing Studies of the Barramiya-Mueilha Sector, Egypt. Remote Sensing. 2019;11(18):2122-2122. Available from: https://dx.doi.org/10.3390/rs11182122. 
17) Zoheir B, Emam A, Abdel-Wahed M, Soliman N. Multispectral and Radar Data for the Setting of Gold Mineralization in the South Eastern Desert, Egypt. Remote Sensing. 2019;11(12). Available from: https://dx.doi.org/10.3390/rs11121450.

18) Ichang'i D, Maclean W. The Archean volcanic facies in the Migori segment. J Afr Earth Sci. 1991;13(3/4):277-290.

19) Shackleton R. Geology of the Migori gold belt. Geol Surv Kenya. 1946;10.

20) Akech NO, Omuombo CA, Masibo M. General geology of Kenya. Developments in Earth Surface Processes. Elsevier. $2013 . \quad$ Available from: https://doi.org/10.1016/B978-0-444-59559-1.00001-3.

21) Rmdc F. Mapping hydrothermal gold mineralization using Landsat 8 data. A case of study in Chaves license, Portugal. Portugal: Departamento de Geociências, Ambiente e Ordenamento do Território. 2015.

22) Mwaniki MW, Moeller MS, Schellmann G. A comparison of Landsat 8 (OLI) and Landsat 7 (ETM+) in mapping geology and visualising lineaments: A case study of central region Kenya. In: and others, editor. ISPRS - International Archives of the Photogrammetry, Remote Sensing and Spatial Information Sciences;vol. XL-7/W3. Copernicus GmbH. 2015;p. 897-903. Available from: https://dx.doi.org/10.5194/isprsarchives-xl-7-w3-897-2015. doi:10.5194/isprsarchives-xl-7-w3-897-2015.

23) Han T, Nelson J. Mapping hydrothermally altered rocks with Landsat 8 imagery : A case study in the KSM and Snow field zones, northwestern British Columbia. In: and others, editor. Geological Fieldwork 2014, British Columbia Ministry of Energy and Mines, British Columbia Geological Survey Paper;vol. 2015. 2015;p. 103-112.

24) Goetz A. Three decades of hyperspectral remote sensing of the Earth: A personal view. Remote Sensing of Environment. 2009;113:5-16. Available from: https://doi.org/10.1016/j.rse.2007.12.014.

25) Carranza EJM, Hale M. Mineral imaging with Landsat Thematic Mapper data for hydrothermal alteration mapping in heavily vegetated terrane. International Journal of Remote Sensing. 2002;23:4827-4852. Available from: https://dx.doi.org/10.1080/01431160110115014.

26) Ali A, Pour A. Lithological mapping and hydrothermal alteration using Landsat 8 data: a case study in ariab mining district, red sea hills, Sudan. International Journal of Basic and Applied Sciences. 2014;3(3). Available from: https://dx.doi.org/10.14419/ijbas.v3i3.2821.

27) Burton-Johnson A, Black M, Fretwell PT, Kaluza-Gilbert J. An automated methodology for differentiating rock from snow, clouds and seain Antarctica from Landsat 8 imagery: a new rock outcrop map and areaestimation for the entire Antarctic continent. The Cryosphere. 2016;10(4):1665-1677. Available from: https://dx.doi.org/10.5194/tc-10-1665-2016.

28) Banerjee K, Jain MK, Jeyaseelan AT, Panda S. Landsat 8 OLI Data for Identification of Hydrothermal Alteration Zone in Singhbhum Shear Zone using Successive Band Depth Difference Technique-A New Image Processing Approach. Current Science. 2019;116(10). Available from: https://dx.doi.org/10. $18520 / \mathrm{cs} / \mathrm{v} 116 / \mathrm{i} 10 / 1639-1647$ 